\title{
UKURAN PERUSAHAAN DAN GOOD CORPORATE GOVERNANCE TERHADAP TERJADINYA KONDISI FINANCIAL DISTRESS
}

\author{
Anne Selvytania \\ aselvytania@gmail.com \\ Ellen Rusliati \\ Fakultas Ekonomi dan Bisnis, Universitas Pasundan Bandung \\ diterima: 10/4/2019; direvisi: 22/7/2019; diterbitkan: 31/8/2019
}

\begin{abstract}
This study aims to determine how the influence of firm size and good corporate governance on the occurrence of financial distress in various industrial sector companies listed on the Indonesia Stock Exchange during 2012-2017. The research method used is descriptive and verifiative. The sample used were 5 sector companies which were done by purposive sampling. Data analysis method used was panel data regression analysis using Eviews 9. The results showed that simultaneously the size of the company and good corporate governance have effect on the occurrence of financial distress conditions about $69.2 \%$. Partially the size of the company has an effect of $39.7 \%$, institutional ownership has an effect $22.4 \%$ on the occurrence of financial distress, while managerial ownership has an effect of $7.1 \%$ but not significant.
\end{abstract}

Keywords: size of company; good corporate governance; managerial ownership; institutional ownership; financial distress

\begin{abstract}
Abstrak
Penelitian ini bertujuan untuk mengetahui pengaruh ukuran perusahaan dan good corporate governance terhadap terjadinya kondisi financial distress pada perusahaan sektor aneka industri yang terdaftar di Bursa Efek Indonesia periode 2012-2017. Metode penelitian yang digunakan adalah deskriptif dan verifikatif. Sampel yang digunakan sebanyak 5 perusahaan, dengan teknik purposive sampling. Metode analisis data yang digunakan adalah analisis regresi data panel menggunakan Eviews 9. Hasil penelitian menunjukkan bahwa secara simultan ukuran perusahaan dan good corporate governance berpengaruh terhadap terjadinya kondisi financial distress yaitu sebesar $69,2 \%$. Secara parsial ukuran perusahaan berpengaruh sebesar 39,7\% dan kepemilikan manajerial berpengaruh terhadap terjadinya financial distress sebesar $22,4 \%$ sedangkan kepemilikan manajerial secara parsial berpengaruh sebesar 7,1\%, namun tidak signifikan.
\end{abstract}

Kata Kunci: ukuran perusahaan; good corporate governance; kepemilikan manajerial; kepemilikan institusional; financial distress 


\section{PENDAHULUAN}

Situasi perekonomian yang selalu berubah-ubah telah mempengaruhi kegiatan dan kinerja perusahaan, baik perusahaan kecil maupun perusahaan besar sehingga banyak perusahaan yang mengalami kebangkrutan. Berdasarkan data 2012 - 2017 Bursa Efek Indonesia (BEI) telah banyak melakukan penghapusan pencatatan efek (delisting) pada perusahaan yang mengalami kesulitan dalam keuangan.

Terdapat 19 perusahaan yang dinyatakan delisting dari berbagai sektor ditunjukkan pada Tabel 1. Sektor tertinggi sebesar $36 \%$ adalah manufaktur. Hal ini disebabkan perusahaan tidak mampu menilai dan memprediksi kondisi perusahaanya. Prediksi ini penting bagi perusahaan guna menghindari kebangkrutan atau mengantisipasi lebih awal kondisi keuangan sebelum terjadinya kebangkrutan atau financial distress (kesulitan keuangan).

Perusahaan manufaktur terdiri dari berbagai sektor, salah satunya yaitu sektor aneka industri. Kinerja industri manufaktur Indonesia saat ini sedang menghadapi sejumlah masalah. Pada tahun 2012, industri manufaktur memberikan konstribusi terhadap PDB sebesar 21,45\% dan terus menurun hingga mencapai $20,84 \%$ ditahun 2015 (kementrian perindustrian, 2016). Selain itu data dari BAPPENAS menyatakan bahwa kurs dolar Amerika Serikat menguat dari 2012 sampai 2015 sebesar Rp. 13.792 terhadap rupiah. Hal ini memberikan dampak yang kurang baik khusunya bagi sektor aneka industri yaitu menyebabkan biaya produksi yang dikeluarkan perusahaan dari tahun ke tahun mengalami pembengkakkan dikarenakan kebanyakan perusahaan industri yang membutuhkan bahan baku yang didapat dari luar negri, sehingga membuat biaya impor menjadi meningkat dan menyebabkan penurunan daya saing juga.

Pengaruh adanya MEA (Masyarakat Ekonomi ASEAN) yang berlaku pada akhir tahun 2015 juga menjadi salah satu faktor yang menyebabkan banyak sektor aneka industri yang belum siap bersaing dengan berbagai industri lainya. Dilansir dari Tempo.com Jakarta, 8 Januari 2015 menyebutkan bahwa siap atau tidak Masyarakat Ekonomi ASEAN (MEA) akan tetap berlaku akhir tahun ini, namun dalam menghadapinya pemerintah telah melakukan identifikasi terhadap beberapa perusahaan yang rawan terkena dampak buruk dalam persaingan se-Asia Tenggara ini. Direktur Jenderal Kerjasama Perdagangan Internasional Bachrul Chairi menyatakan hasil studi yang dilakukan Kementrian Perindustrian bahwa sektor yang paling rentan terpengaruh oleh MEA yaitu daya saing di sektor industri. Beberapa sektor itu menurut Bahcrul adalah industri tekstil, alas kaki, elektronik, baja, kulit, dan beberapa produk pertanian.

Gambar 1 menunjukkan kondisi perusahaan yang diprediksi mengalami financial distress periode 2012-2017 yang fluktuatif dengan kecenderungan meningkat. Hal ini disebabkan oleh semakin lemahnya ekonomi Indonesia yang tercermin dari kurs nilai dollar Amerika terhadap rupiah yang semakin tinggi sehingga menyebabkan semakin meningkatnya biaya yang dikeluarkan perusahaan.

Penelitian ini menggunakan faktor internal perusahaan yang dapat mempengaruhi kondisi financial distress yaitu ukuran suatu perusahaan, menunjukkan besarnya total aset yang dimiliki. Selain itu juga good corporate governance yang menjadi topik utama dalam lingkungan bisnis. Konsep good corporate governance diperkenalkan di negera-negara maju dengan adanya konsep pemisahan kepentingan antara pemilik dengan manajemen perusahaan, dikenal dengan agency theory. Good corporate governance dalam penelitian ini diproksikan dengan struktur kepemilikan yang terdiri dari kepemilikan manajerial dan kepemilikan konstirusional (Triwahyuningtias, 2012).

Kepemilikan manajerial merupakan proporsi kepemilikan perusahaan oleh manajemen (direksi). Semakin besar proporsi kepemilikan manajemen maka semakin besar pula tanggung jawabnya dalam mengelola perusahaan. Kurangnya kepemilikan manajemen menjadi berkurangnya tanggungjawab manajemen terhadap perusahaan dapat memicu timbulnya resiko yang dapat membuat perusahaan mengalami financial distress (Manurung, 2016).

Struktur kepemilikan selain kepemilikan manajerial untuk memprediksi financial distress, yaitu kepemilikan institusional. Kepemilikan institusional merupakan kepemilikan saham perusahaan yang dimiliki oleh institusi seperti perusahaan asuransi, bank, perusahaan investasi, dan kepemilikan institusi lain. Semakin berkurangnya kepemilikan saham oleh institusi dibandingkan dengan keseluruhan saham yang dimiliki menunjukkan bahwa masih kurang efisien pemanfaatan aktiva perusahaan, selain itu penurunan kepemilikan ini mengindikasikan kemampuan monitoring atau pengawasan perusahaan yang kurang sehingga akhirnya akan mendorong semakin besarnyanya potensi kesulitan keuangan yang mungkin terjadi dalam perusahaan (Cinantya dan Merkusiwati, 2015).

Rumusan masalah adalah (1) Bagaimana kondisi ukuran perusahaan, good corporate governance dan financial distress pada perusahaan sektor aneka industri yang terdaftar di Bursa Efek Indonesia periode 20122017, (2) Seberapa besar pengaruh ukuran perusahaan dan good corporate governance (kepemilikan manajerial dan institusional) secara simultan terhadap kondisi financial distress pada perusahaan sektor aneka industri yang terdaftar di Bursa Efek Indonesia periode 20122017, secara simultan dan parsial. Paradigma penelitian ditunjukkan pada Gambar 2.

Hipotesis yang diajukan adalah: (1) Terdapat pengaruh Ukuran Perusahaan dam Corporate Governance terhadap terjadinya kondisi Financial distress, (2) Terdapat pengaruh Ukuran Perusahaan 
terhadap terjadinya kondisi Financial distress, (3) Terdapat pengaruh Corporate Governance yaitu Kepemilikan Manajerial terhadap terjadinya kondisi Financial distress, (4) Terdapat pengaruh Corporate Governance yaitu Kepemilikan Institusional terhadap terjadinya kondisi Financial distress

\section{METODE}

Metode yang digunakan yaitu metode deskriptif dan verifikatif. Populasi adalah perusahaan Sektor Aneka Industri yang terdaftar di Bursa Efek Indonesia tahun 2012-2017 yaitu 39 perusahaan. Teknik pengambilan sampel menggunakan metode purposive sampling, diperoleh sebanyak 5 Perusahaan, yaitu Astra Internasional Tbk, Goodyear Indonesia Tbk, Gajah Tunggal Tbk, Prima Alloy Steel Universal Tbk, Sunson Textile Manufacturer Tbk. Teknik pengumpulan data yang dilakukan adalah studi kepustakaan, observasi tidak langsung ke situs www.idx.co.id, www.sahamoke.com., dan ICMD tahun 2012 - 2016, serta studi dokumentasi. Teknik analisis data adalah analisis deskriptif dan $n$ verifikatif, menggunakan analisis regresi data panel menggunakan software Microscoft excel, SPSS, dan Eviews 9. Data diperoleh dari laporan keuangan perusahaan Sektor Aneka Industri yang terdaftar di Bursa Efek Indonesia periode 2012-2017.

\section{HASIL}

Hasil perhitungan statistik deskriptif terhadap 5 sampel perusahaan sub sektor aneka industri yang terdaftar di Bursa Efek Indonesia periode 2012-2017 dapat dilihat pada Tabel 2.

Tabel 2 menunjukkan nilai mean ukuran perusahaan sebesar 15,42 yang artinya total asset cukup besar. Good corporate governance diukur dengan kepemilikan manajerial diperoleh nilai mean sebesar 6,388 yang artinya kepemilikan manajerial pada perusahaan sektor aneka industri rendah. Good corporate governance yang diukur dengan kepemilikan institusional diperoleh nilai mean sebesar 61,61, yang artinya kepemilikan institusional pada perusahaan sektor aneka industri cukup tinggi, disebabkan oleh efektifnya pengelolaan asset yang dimiliki perusahaan. Financial distress yang diproksikan menggunakan Altman Z-score diperoleh nilai mean sebesar 1,66 yang artinya berada dalam kondisi tidak baik atau berada pada zona distress, karena sebagian besar perusahaan mengalami nilai Z-Score yang kurang dari 1,8. Nilai standar deviasi ukuran perusahaan, kepemilikan institusional, dan financial distress yang lebih kecil dari rata-rata, menunjukkan rendahnya variasi antara nilai maksimum dan nilai minimum. Namun tidak untuk GCG yang diukur dengan kepemilikan manajerial.

Gambar 3 menunjukkan kondisi ukuran perusahaan dengan menggunakan Ln Total Asset cenderung mengalami peningkatan, namun mengalami penurunan pada tahun 2016 dan 2017. Menurut www.bi.go.id, $\mathrm{BI}$ mengubah $\mathrm{BI}$ rate menjadi BI 7-days repo rate mempengaruhi perekonomian makro melalui perubahan harga asset, kenaikan suku bunga akan menurunkan harga asset seperti saham dan obligasi sehingga mengurangi kekayaan individu dan perusahaan yang akhirnya mengurangi kemampuan untuk melakukan kegiatan ekonomi seperti konsumsi dan investasi.

Gambar 4 menunjukkan kondisi rata-rata kepemilikan manajerial pada tahun 2012 sebesar $4,53 \%$ kemudian mengalami penurunan selanjutnya mengalami kenaikan pada tahun 2016 dan 2017. Penurunan disebabkan rata-rata IHSG mengalami fluktuasi. Sektor aneka industri memang tidak pernah lepas dari Astra Internasional, menurut Bima (CNN Indonesia, 2017), hal tersebut memicu investor untuk kurang tertarik membeli saham sektor insdustri dan lebih dapat meningkatkan kepemilikan manajerial.

Berdasarkan Gambar 5 dapat diketahui bahwa pada tahun 2012 kepemilikan institusional sebesar $63,14 \%$, kemudian meningkat pada 3 tahun berikutnya, sedangkan pada tahun 2016 mengalami penurunan dan naik kembali pada tahun 2017. Kenaikan ini disebabkan IHSG sektor aneka industri mengalami fluktuasi dari tahun 2012-2017 berdasarkan informasi yang didapat dari CNN Indonesia (Maret 2017) kenaikan dan penurunan harga saham dapat membantu investor dalam mengambil keputusan investasinya.

Berdasarkan Gambar 6 kondisi rata-rata kondisi financial distress mengalami fluktuasi dan cenderung menurun. Secara umum kenaikan dan penurunan nilai Z-score $<1,8$ artinya perusahaan diprediksi mengalami financial distress. Hal ini disebabkan oleh berbagai faktor baik dari dalam maupun luar perusahaan, salah satunya nilai kurs dollar terhadap rupiah yang terus meningkat mengakibatkan biaya produksi meningkat karena bahan baku perusahaan yang tergantung dari luar negeri. Kemudian pengaruh persaingan adanya MEA dimana perusahaan masih kalah bersaing yang berdampak pada kinerja.

Hasil uji asumsi klasik menunjukkan bahwa data berdistribusi normal, tidak terjadi multikolinieritas, heteroskedastisitas, dan autokorelasi. Selanjutnya dilakukan uji Chow (Tabel 3) diperoleh nilai probability F adalah 0,013 artinya model yang terpilih adalah model fixed effect, kemudian dilanjutkan menggunakan uji Hausman untuk memilih model antara fixed effect dan random effect.

Hasil uji Hausman (Tabel 4) diperoleh nilai probability $\mathrm{F}$ adalah 0,0593 artinya model yang terpilih adalah model random effect, maka pengujian dilanjutkan menggunakan Uji Langrange Multiplier untuk memilih model antara random effect dan common effect (Tabel 5) dapat diketahui bahwa hasil Both Breusch-Pagan adalah sebesar 0,8540 menunjukkan bahwa common effect merupakan pilihan yang tepat untuk estimasi model. 
Berdasarkan Tabel 6, dapat diketahui bahwa pengaruh ukuran perusahaan dan good corporate governance terhadap terjadinya kondisi financial distress pada perusahaan sektor aneka industri yang terdaftar di Bursa Efek Indonesia periode 2012-2017 diperoleh hasil regresi dengan sebgai berikut:

$Y=-6,92+0,366 X_{1}+0,0194 X_{2}+0,0458 X_{3}$

$\mathrm{Y}=$ Financial distress

$\mathrm{X}_{1}=$ Ukuran perusahaan

$\mathrm{X}_{2}=$ Kepemilikan manajerial

$\mathrm{X}_{3}=$ Kepemilikan institusional

Berdasarkan Tabel 7 dapat diketahui bahwa ukuran perusahaan dan good corporate governance yaitu kepemilikan manajerial dan kepemilikan institusional secara simultan berpengaruh terhadap financial distress pada perusahaan manufaktur sektor aneka industri yang terdaftar di Bursa Efek Indonesia sebesar 61,62\%.

Berdasarkan Tabel 8 diketahui: (1) Pengaruh ukuran perusahaan terhadap financial distress $=0,740 \times 0,537$ $=0,397$ atau $39,7 \%$, (2) Pengaruh good corporate governance yaitu kepemilikan manajerial terhadap financial distress $=0,179 \times 0,395=0,071$ atau 7,1\%, (3) Pengaruh good corporate governance yaitu kepemilikan institusional terhadap financial distress $=0,634 \times 0,354$ $=0,224$ atau $22,4 \%$

Berdasarkan perhitungan dapat diketahui bahwa ukuran perusahaan memiliki kontribusi dominan terhadap financial distress sebesar 39,7\%. Good corporate governance yaitu kepemilikan manajerial terhadap financial distress memiliki kontribusi sebesar $7,1 \%$, serta untuk kepemilikan institusional terhadap financial distress memiliki kontribusi sebesar 22,4\%.

\section{PEMBAHASAN}

Ukuran perusahaan dan good corporate governance (kepemilikan manajerial dan kepemilikan institusional) mempengaruhi financial distress pada perusahaan sektor industri yang terdaftar di Bursa Efek Indonesia periode 2012-2017 sebesar 69,2\%. Hasil ini sejalan dengan penelitian Murhadi, et. al. (2018), Helgawati (2017).

Ukuran Perusahaan akan mempengaruhi kondisi Financial Distress dengan memberikan kontribusi sebesar 39,7\%. Hasil ini sejalan dengan penelitian Astuti dan Pamudji (2015), Murhadi, et.al. (2018), Muhtar (2017), dan Wangige (2016).

Besar kecilnya GCG (kepemilikan manajerial) tidak akan mempengaruhi kondisi financial distress pada perusahaan karena memberikan pengaruh sebesar 7,1\%, dan tidak signifikan. Hasil ini sejalan dengan penelitian Cinantya dan Merkusiwati (2015) Hal ini disebabkan karena kepemilikan manajerial hanya simbolis saja yang hanya dimanfaatkan untuk menarik perhatian investor. Sedangkan yang tidak sejalan dengan penelitian ini dikemukakan oleh Hanifah (2013). Pernyataan yang sama didukung oleh penelitian yang dilakukan oleh Manurung (2016), Sunarwijaya (2015), dan Murhadi, et. al. (2018).

Besar kecilnya GCG (kepemilikan institusional) akan mempengaruhi kondisi financial distress perusahaan sebesar $22,4 \%$. Penelitian ini diperkuat oleh agency theory yang dikemukakan oleh Jensen dan Meckling (1976) dalam Sipahutar (2014), Cinantya dan Merkusiwati (2015), Hanifah (2013), Shah (2016) dan Udin (2017). Perbedaan yang dilakukan penulis dengan penelitian sebelumnya adalah pada sampel penelitian yang digunakan yaitu dengan Cinantya dan Merkusiwati (2015) Hanifah (2013), Murhadi, et. al. (2018) dan Syed (2016).

\section{KESIMPULAN}

Berdasarkan hasil penelitian dapat ditarik kesimpulan sebagai berikut: (1) Kondisi ukuran perusahaan, kepemilikan institusional, dan financial distress pada perusahaan sektor aneka industri yang terdaftar di Bursa Efek Indonesia periode 20122017 mengalami peningkatan kemudian menurun. Hal sebaliknya terjadi pada kepemilikan manajerial. (2) Besarnya pengaruh ukuran perusahaan dan good corporate governance (kepemilikan manajerial dan kepemilikan institusional) terhadap kondisi financial distress pada perusahaan sektor aneka industri yang terdaftar di Bursa Efek Indonesia periode 2012-2017 secara simultan sebesar 69\%. (3) Besarnya pengaruh ukuran perusahaan terhadap financial distress pada perusahaan sektor aneka industri yang terdaftar di Bursa Efek Indonesia periode 2012-2017 sebesar $39,7 \%$. Besarnya pengaruh kepemilikan institusional berpengaruh sebesar $22,4 \%$, sedangkan kepemilikan manajerial sebesar 7,1\%, namun tidak signifikan.

\section{DAFTAR PUSTAKA}

Astuti, Puji dan Sugeng Pamudji. 2015. Analisis Pengaruh Opini Going Concern, Likuiditas, Umur perusahaan dan Ukuran Perusahaan terhadap Kemungkinan Financial distress. ejournal-s1.undip. ac.id/ Volume 4, Nomor 1.

Bodie, Z.; Kane, A. \& Marcus, AJ. 2011. Investments and Portfolio Management. Global Edition. The Mc, Graw-Hill Companies. New York.

Cinantya, I Gusti Agung Ayu Pritha dan Ni Ketut Lely Aryani Merkusiwati. 2015. Pengaruh Corporate Governance, Financial Indicators Dan Ukuran Perusahaan Pada Financial Distress. E-Journal Akuntansi. Universitas Udayana, Vol. 10. No. 3. Maret. Cornett, Marcia; Troy Adair Troy; and John Nofsinger. 2012. Finance Application and Theory. Second Edition. Mc Graw-Hill/Irwin, New York.

Hanifah, Oktita Earning, 2013. Pengaruh Struktur 
Corporate Governance dan Financial Indicators Terhadap Kondisi Financial Distress, Diponegoro Journal of Accounting vol. 2, no 2, p.1-15. ISSN 2337-3806

Hartono, Jogiyanto. 2013. Teori Portofolio dan Analisis Investasi. Edisi Kedelapan. BPFE Yogyakarta.

Helgawati, Mega. 2017. Pengaruh Penerapan Tata kelola Perusahaan, ukuran perusahaan dan Leverage terhadap Financial Distress pada Perusahaan CGPI yang Terdaftar di BEI periode 2011-2014. repository.unpas.ac.id.

ICMD. 2012. Indonesia Capital Market Drectory, Jakarta, Indonesia.

ICMD. 2013. Indonesia Capital Market Drectory, Jakarta, Indonesia.

ICMD. 2014. Indonesia Capital Market Drectory, Jakarta, Indonesia.

ICMD. 2015. Indonesia Capital Market Drectory, Jakarta, Indonesia.

ICMD. 2016. Indonesia Capital Market Drectory, Jakarta, Indonesia.

IDX Fact Book 2012-2016. Jakarta, Research Division Bursa Efek Indonesia.

Manurung, Irawati, C Handoyo Wibisono. 2016. Analisis Pengaruh Struktur Kepemilikan, Likuiditas dan Leverage terhadap Financial distress pada Perusahaan manufaktur yang terdaftar di Bursa Efek Indonesia tahun 2009-2014. e-journal.uajy.ac.id

Muhtar, Mutiara. 2017. Pengaruh Kinerja Keuangan Terhadap Terjadinya Kondisi Financial Distress Pada Perusahaan Telekomunikasi di Indonesia. repository.unhas.ac.id

Murhadi, Werner Ria; Felicia Tanugara, \& Bertha Silvia Sutejo. 2018. The Influence of Good Corporate Governance on Financial Distress. Advances in

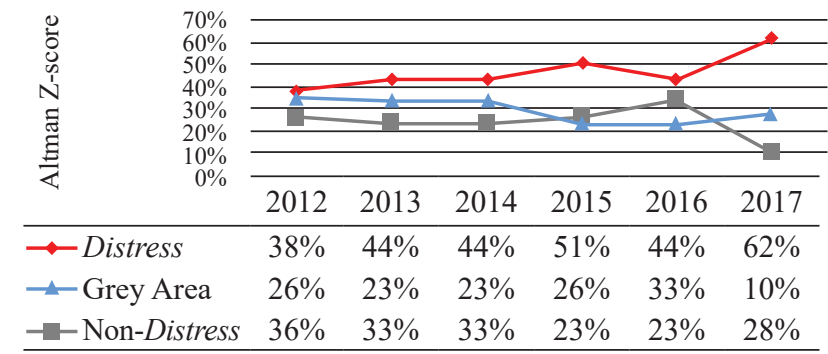

Sumber : ICMD 2013 dan 2017 (diolah)

Gambar 1. Grafik Persentase Perusahaan yang Diprediksi Mengalami Financial Distress Pada Perusahaan Sektor Aneka Industri Periode 2012-2017
Social Science, Education and Humanities Research (ASSEHR), volume 186.

Shah, SBH. 2016. The Impact of Corporate Governance on Financial Distress; Evidence from Pakistan. https://thesis.cust.edu.pk

Sipahutar, Santy Surya. 2014. Analisis Pengaruh Ukuran Perusahaan dan Corporate Governance Terhadap Terjadinya Kondisi Financial Distress.https://www. scribd.com/document

Sunarwijaya, I Ketut. 2015. Pengaruh Likuiditas, Kepemilikan Manajerial dan Kepemilikan Institusional terhadap Kemungkinan terjadinya Financial Distress. $\mathrm{https} / /$ media.neliti.com/media/publication

Triwahyuningtias, M. dan H. Muharam. 2012. Analisis Pengaruh Struktur Kepemilikan, Ukuran Dewan, Komisaris Independen, Likuiditas, dan Leverage Terhadap Terjadinya Kondisi Financial Distress (Studi Pada Perusahaan Manufaktur yang Terdaftar di Bursa Efek Indonesia Tahun 2008-2010). Diponegoro Journal of Management 1(1): 1-14

Udin, Shahab; Muhammad Arshad Khan; and Attiya Yasmin Javid. 2017. The Effects of Ownership Structure on Likelihood of Financial Distress: an Empirical Evidence. Corporate Governance. The International Journal of Business in Society, Vol. 17 Issue: 4, pp.589-612.

Wangige, Gathecha John. 2016. Effect of Firm Characteristics on Financial distress of NonFinancial Firms Listed at Nairobi Securities exchange, Kenya. https://ir-library.ku.ac.ke www.idx.co.id www.sahamok.com www.kemenperin.go.id m.cnnindonesia.com www.bi.go.id

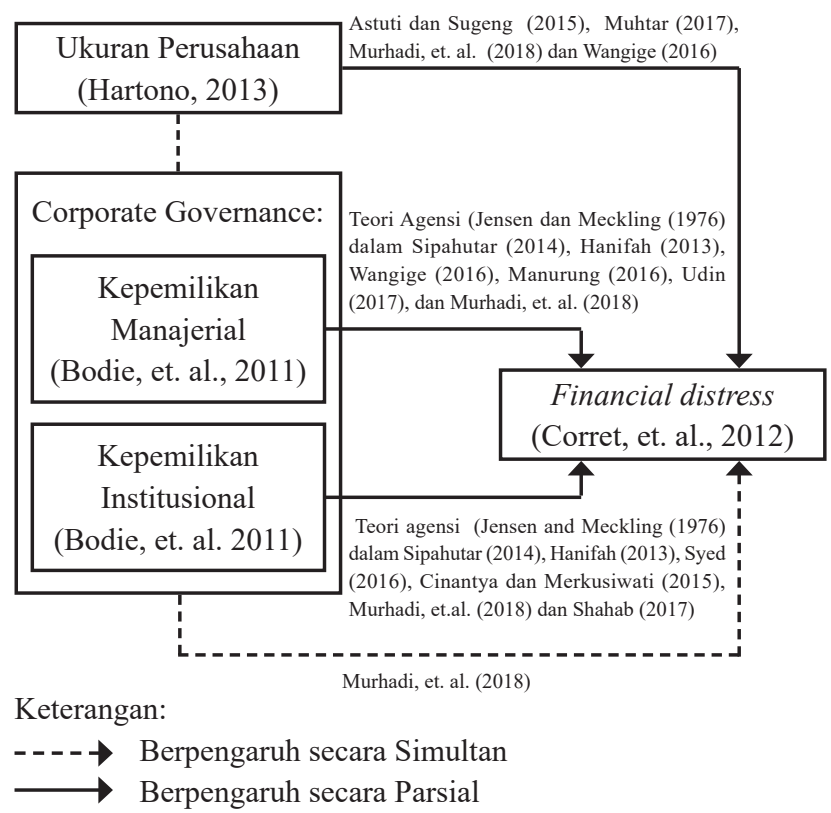

Gambar 2. Paradigma Penelitian 


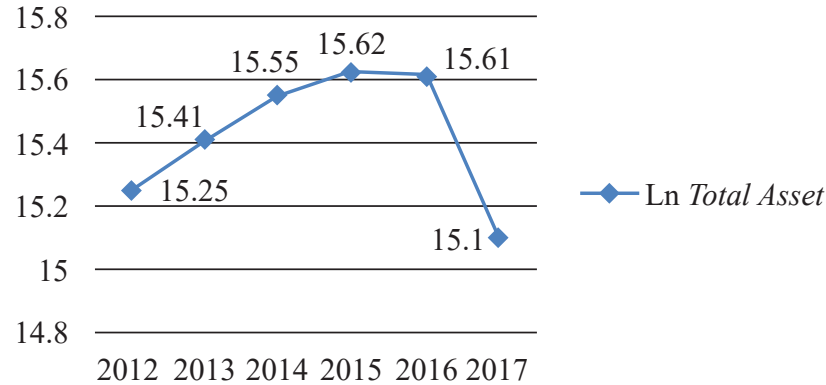

Sumber: Data sekunder yang diolah peneliti

Gambar 3. Kondisi Rata-rata Ukuran Perusahaan pada Perusahaan Manufaktur Sektor Aneka Industri yang terdaftar di Bursa Efek Indonesia selama periode tahun 2012-2017

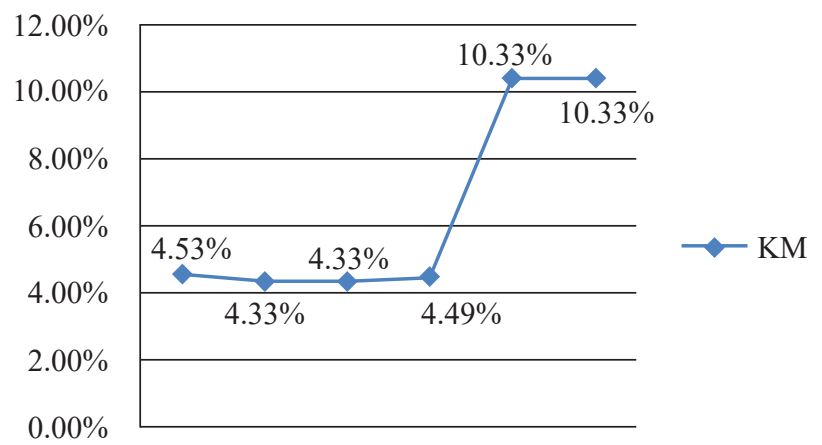

201220132014201520162017

Sumber: Data sekunder yang diolah peneliti

Gambar 4. Kondisi Rata-rata Kepemilikan Manajerial pada Perusahaan Manufaktur Sektor Aneka Industri yang terdaftar di Bursa Efek Indonesia selama periode tahun 2012-2017

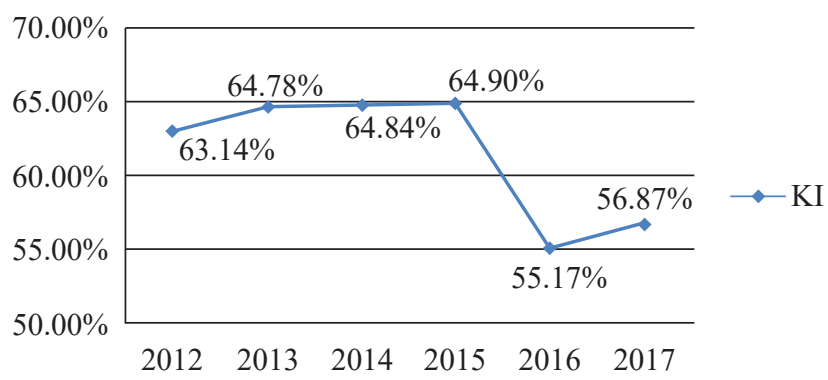

Sumber: Data sekunder yang diolah peneliti

Gambar 5. Kondisi Rata-rata Kepemilikan Institusional pada Perusahaan Manufaktur Sektor Aneka Industri yang terdaftar di Bursa Efek Indonesia selama periode tahun 2012-2017

Rata-rata Prediksi Financial Distress (Altman Z-score)

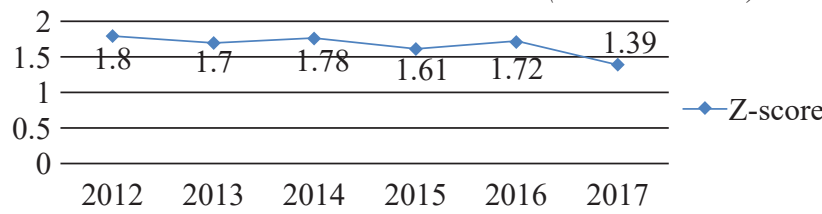

Sumber: Data sekunder yang diolah peneliti

Gambar 6. Kondisi rata-rata kondisi Financial Distress pada Perusahaan Manufaktur Sektor Aneka Industri yang terdaftar di Bursa Efek Indonesia selama periode tahun 2012-2017
Tabel 1. Perusahaan yang Delisting di BEI tahun 2012 - 2017

\begin{tabular}{lcc}
\hline \multicolumn{1}{c}{ Sektor } & Jumlah Perusahaan & Persentase \\
\hline Utama & 2 & $8 \%$ \\
Manufaktur & 9 & $36 \%$ \\
Keuangan & 6 & $24 \%$ \\
Jasa & 8 & $32 \%$ \\
Jumlah & 25 & $100 \%$ \\
\hline
\end{tabular}

Sumber: factbook BEI dan www.sahamok.com

Tabel 2. Statistik Deskriptif

\begin{tabular}{lcccc}
\hline & FD & SIZE & KM & KI \\
\hline Mean & 1.666333 & 15.42400 & 6.388000 & 61.61681 \\
Median & 1.680000 & 14.25500 & 5.000000 & 60.00000 \\
Maximum & 3.330000 & 19.50000 & 37.00000 & 90.70732 \\
Minimum & 0.350000 & 11.73000 & 0.040000 & 41.00000 \\
Std. Dev. & 0.900511 & 2.314915 & 9.035511 & 14.64435 \\
Skewness & 0.151283 & 0.647881 & 2.600278 & 0.777428 \\
Kurtosis & 1.761737 & 2.081413 & 9.490993 & 2.642856 \\
Jarque-Bera & 2.031052 & 3.153499 & 86.47347 & 3.181414 \\
Probability & 0.362212 & 0.206646 & 0.000000 & 0.203781 \\
Sum & 49.99000 & 462.7200 & 191.6400 & 1848.504 \\
Sum Sq. Dev. & 23.51670 & 155.4061 & 2367.573 & 6219.249 \\
Observations & 30 & 30 & 30 & 30 \\
\hline Sumber: Data sekunder yang diolah dengan Eviews 9 &
\end{tabular}

Sumber: Data sekunder yang diolah dengan Eviews 9

Tabel 3. Hasil Chow Test Untuk Menguji Common/Fixed Model Redundant Fixed Effects Tests

Equation: CHOW_TEST

Test cross-section fixed effects

\begin{tabular}{lrrc}
\hline Effects Test & Statistic & d.f. & Prob. \\
\hline Cross-section F & 4.047897 & $(4,22)$ & 0.0131 \\
Cross-section Chi-square & 16.547186 & 4 & 0.0024 \\
\hline
\end{tabular}

Sumber: Olah Data Eviews 9

Tabel 4. Hasil Hausman Test Untuk Menguji Random/Fixed Model Correlated Random Effects - Hausman Test Equation: HAUSMAN_TEST

Test cross-section random effects

\begin{tabular}{llrl}
\hline Test Summary & $\begin{array}{l}\text { Chi-Sq. } \\
\text { Statistic }\end{array}$ & $\begin{array}{c}\text { Chi-Sq. } \\
\text { d.f. }\end{array}$ & Prob. \\
\hline Cross-section random & 7.431520 & 3 & 0.0593 \\
\hline
\end{tabular}

Sumber: Olah Data Eviews 9

Tabel 5. Hasil Uji LM (Lagrange Multiplier Test)

Lagrange Multiplier Tests for Random Effects

Null hypotheses: No effects

Alternative hypotheses: Two-sided (Breusch-Pagan) and one-sided (all others) alternatives

\begin{tabular}{lrcc}
\hline & \multicolumn{3}{c}{ Test Hypothesis } \\
\hline Cross-section & Time & Both \\
\hline 0.033855 & 1.915173 & 1.949029 \\
& $(0.8540)$ & $(0.1664)$ & $(0.1627)$ \\
\hline
\end{tabular}

Sumber: Olah Data Eviews 9 
Tabel 6. Analisis Regresi Data Panel

Dependent Variable: FD

Method: Panel Least Squares

Date: 09/22/18 Time: 16:18

Sample: 20122017

Periods included: 6

Cross-sections included: 5

Total panel (balanced) observations: 30

\begin{tabular}{lrrrr}
\hline \multicolumn{1}{c}{ Variable } & Coefficient & Std. Error & t-Statistic & Prob. \\
\hline C & -6.920943 & 1.331144 & -5.199243 & 0.0000 \\
SIZE & 0.365855 & 0.060478 & 6.049366 & 0.0000 \\
KM & 0.019425 & 0.014286 & 1.359774 & 0.1856 \\
KI & 0.045771 & 0.007986 & 5.731317 & 0.0000 \\
\hline
\end{tabular}

Sumber: Olah data Eviews 9
Tabel 7. Hasil Uji F

\begin{tabular}{llll}
\hline R-squared & 0.691739 & Mean dependent var & 1.666333 \\
Adjusted R-squared & 0.656171 & S.D. dependent var & 0.900511 \\
S.E. of regression & 0.528032 & Akaike info criterion & 1.684248 \\
Sum squared resid & 7.249273 & Schwarz criterion & 1.871074 \\
Log likelihood & -21.26371 & Hannan-Quinn criter. & 1.744015 \\
F-statistic & 19.44807 & Durbin-Watson stat & 1.082873
\end{tabular}

Prob(F-statistic) $\quad 0.000001$

Sumber: Olah data Eviews 9

Tabel 8. Koefisien Determinasi Parsial

Coefficients $^{\mathrm{a}}$

\begin{tabular}{|c|c|c|c|c|c|c|c|c|c|c|c|}
\hline \multicolumn{2}{|c|}{ Model } & \multicolumn{2}{|c|}{$\begin{array}{c}\text { Unstandardized } \\
\text { Coefficients }\end{array}$} & \multirow{2}{*}{$\begin{array}{c}\begin{array}{c}\text { Standardized } \\
\text { Coefficients }\end{array} \\
\text { Beta }\end{array}$} & \multirow[t]{2}{*}{$\mathrm{t}$} & \multirow[t]{2}{*}{ Sig. } & \multicolumn{3}{|c|}{ Correlations } & \multicolumn{2}{|c|}{$\begin{array}{c}\text { Collinearity } \\
\text { Statistics } \\
\end{array}$} \\
\hline & & B & $\begin{array}{l}\text { Std. } \\
\text { Error }\end{array}$ & & & & $\begin{array}{l}\text { Zero- } \\
\text { order }\end{array}$ & Partial & Part & Tolerance & VIF \\
\hline \multirow[t]{4}{*}{1} & (Constant) & $-6,921$ & 1,331 & & $-5,199$ &, 000 & & & & & \\
\hline & Size & ,366 & ,060 & ,740 & 6,049 &, 000 &, 537 & ,765 & ,459 & ,491 & 2,039 \\
\hline & $\mathrm{KM}$ & ,019 & ,014 & , 179 & 1,360 & ,186 & ,395 & ,258 & , 148 & ,577 & 1,733 \\
\hline & $\mathrm{KI}$ & ,046 & ,008 & ,634 & 5,731 &, 000 &, 354 &, 747 & ,324 & ,703 & 1,423 \\
\hline
\end{tabular}

a. Dependent Variable: FD

Sumber: Data tambahan 